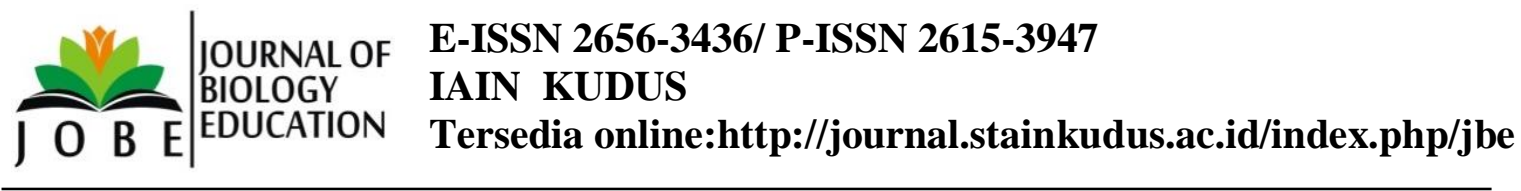

\title{
Keanekaragaman Tanaman Terestrial di Pulau Panjang Jepara
}

\author{
Fara El Alfa Fauzia ${ }^{1}$, Ananda Salsabilla ${ }^{2}$, Andi Asyhari ${ }^{3)}$ \\ Tadris Biologi IAIN Kudus $1,2,3$ \\ ${ }^{1)}$ faraelafaa@gmail.com ${ }^{2)}$ anandasalsabilla5@ gmail.com ${ }^{3)}$ andykalem2014@gmail.com
}

\begin{abstract}
ABSTRAK
Penelitian ini bertujuan untuk mendeskripsikan jenis-jenis keanekaragaman tanaman teresterial yang terdapat di Pulau Panjang, Desa Ujung Batu, Kabupaten Jepara. Pengamatan ini dilaksanakan di hutan pantai yang ada di Pulau Panjang. Metode yang digunakan adalah metode observasi dengan pengambilan data sampel di area seluruh area Pulau Panjang. Data yang diperoleh dianalisis secara deskripstif dengan cara membuat deskripsi dan klasifikasi dari jenis yang ditemukan. Hasil penelitian menemukan 15 spesies yang terdiri atas 10 ordo dan 11 famili, terdiri dari 13 spesies pohon, 1 spesies semak, dan 1 spesies perdu. Adapun tanaman yang mendominasi di Pulau Panjang adalah Casuarina equisetifolia L. (Cemara Laut), Pemphis acidula (Stigi), Leucaena sp. (Lamtoro), Ceiba sp. (Kapuk Randu), Tamarindus sp. (Asam), dan Terminalia sp. (Ketapang).
\end{abstract}

Kata Kunci: Keanekaragaman Tumbuhan, Hutan Pantai, Pulau Panjang.

\section{ABSTRACT}

This research aims to describe the types of terrestrial crops diversity found in Panjang Island, Ujung Batu Village, Jepara Regency. This observation was carried out in the coastal forests of Panjang Island. The method used is the observation method with the capture of sample data in the entire area of Panajang Island. The Data obtained is analyzed descripstive by creating descriptions and classifications of the types found. The results of the study found 15 species consisting of 10 orders and 11 family. Divided into 13 species of trees, 1 species of shrubs, and 1 species of perdu. The dominating plants in the Long Island are Casuarina equisetifolia L. (Sea fir), Pemphis Acidula (Stigi), Leucaena sp. (Lamtoro), Ceiba sp. (Kapuk Randu), Tamarindus sp. (Asam), and Terminalia sp. (Ketapang).

Keywords: Plant Diversity, Beach Forest, Panjang Island

\section{PENDAHULUAN}

Indonesia merupakan negara kepulauan yang luas, dengan tingkat keanekaragaman flora dan fauna yang sangat tinggi sehingga disebut negara megabiodiversity. Indonesia diperkirakan memiliki 90 tipe ekosistem, baik di darat maupun di perairan dan terdapat 15 formasi hutan alam yang memiliki produktifitas 
tinggi. Formasi hutan alam di Indonesia tersebar dari ujung barat dari Sabang sampai ujung Timur dengan beranekaragam jenis hewan dan tumbuhan (Pugesehan, 2011). Serta didukung letak geografisnya yang berada di daerah tropis dengan iklimnya yang khas. Indonesia memiliki sekitar 17.508 pulau dengan panjang pantai sekitar $81.000 \mathrm{~km}$ (Tuhuteru, Mahfudz, 2012). Beberapa pulau besar layaknya pulau Kalimantan, Sumatra, Jawa, Papua, serta dilengkapi belasan ribu pulau kecil, dengan keunikan daerahnya masing-masing. Kawasan pulau kecil dan pesisir Indonesia juga mempunyai sumber daya hayati yang tinggi. Letak kawasan ini berada di daerah pertemuan antara ekosistem darat dan ekosistem laut. Ekosistem alamiah di Indonesia sangat beragam mulai dari daratan (teresterial) hingga perairan (akuatik). Ekosistem pesisir pantai sendiri terbentuk setelah adanya gundukan pasir yang di akibatkan oleh hembusan angin dan hempasan gelombang ke arah daratan. Daerah ini biasanya terdapat hutan yang disebut hutan pantai.

Hutan pantai merupakan tipe hutan yang memiliki fungsi penting dan tumbuh pada lahan kering di sepanjang pesisir pantai, berpasir dan tidak landai, dan berada di atas garis pasang tertinggi (Onrizal dan Kusuma 2004). Selain mangrove hutan pantai penting dalam menjaga stabilitas ekosistem pesisir. Berbeda dengan jenis hutan lainnya hutan pantai memiliki jenis tumbuhan khas yang terbagi dalam dua formasi vegetasi, yaitu pes-caprae dan baringtonia. Hutan pantai Indonesia umumnya terdiri atas berbagai tipe ekosistem hayati, antara lain ekosistem hutan pantai formasi pescaprae, barringtonia dan hutan mangrove. Ekosistem hutan pantai formasi pescaprae biasanya didominasi oleh tumbuhan merayap, sedangkan formasi barringtonia didominasi oleh tumbuhan yang berbentuk pohon (Muanmar, et all, 2017).

Ekosistem pulau kecil merupakan satuan daratan yang bersifat insular (terpisah dari daratan utama atau pulau induk), dengan luas kurang dari $1.000 \mathrm{~km}^{2}$ atau lebarnya kurang dari 10 km (BAPPENAS, 2003). Namun menurut Undang-Undang No.1 Tahun 2014 tentang Pengelolaan Pesisir dan Pulau-Pulau Kecil pasal 1 ayat 3, Pulau Kecil adalah pulau dengan luas lebih kecil atau sama dengan $2.000 \mathrm{~km}^{2}$ (dua ribu kilometer persegi) beserta kesatuan ekosistemnya. Sedangkan pulau yang memiliki ukuran lebih kecil dari $100 \mathrm{~km} 2$ atau lebarnya tidak lebih besar dari $3 \mathrm{~km}$ dikategorikan sebagai pulau sangat kecil (Unesco, 1991). 
Pulau Panjang merupakan salah satu pulau yang dikategorikan sebagai pulaupulau kecil yang terdapat di kelurahan Ujung Batu, kecamatan Jepara, kabupaten Jepara, Provinsi Jawa Tengah. Secara geografis pulau panjang terletak pada posisi $06^{0} 34^{\prime \prime} 30^{\prime}$ LS dan $110^{0} 37^{\prime} 44$ LU. Wilayah perairan Pulau Panjang Jepara merupakan wilayah yang memiliki pasir putih dengan dikelilingi laut dangkal berair jernih serta memiliki terumbu karang yang secara umum memiliki dasar perairan berupa pasir dan pecahan karang serta cangkang organisme laut (Direktorat Pendayagunaan Pulau-Pulau Kecil, 2012).

Pulau panjang merupakan salah satu pulau kecil yang berpotensi untuk dikembangkan. Luas wilayah Pulau Panjang 7 Ha dan dipenuhi pohon-pohon liar. Secara administrasi masuk dalam wilayah Kabupaten Jepara, Jawa Tengah. Pulau Panjang terletak lebih kurang $2 \mathrm{~km}$ dari pantai Kartini Jepara yang bisa dijangkau dengan menggunakan perahu selama kurang lebih 15 menit. Keberadaan pulau-pulau kecil berfungsi sebagai pengatur iklim global, siklus hidrologi dan biogeokimia, penyerap limbah, sumber plasma nutfah dan sistem penunjang kehidupan lainnya (Bengen, 2000).

Sebagian besar vegetasi di pulau kecil merupakan ekosistem alami daratan. Berlangsungnya proses isolasi geografis yang lama akan membentuk pola vegetasi yang khas berbeda dengan tempat yang lain dan kemungkinan terbentuk jenis tumbuhan endemis. Hal ini disebabkan karena adanya mekanisme adaptasi tumbuhan terhadap lingkungannya dalam waktu yang lama (Mirmanto, 2010). Spesies endemik merupakan jenis tumbuhan yang hanya ditemukan dalam wilayah terbatas pada daerah tertentu, sehingga keberadaannya perlu dijaga dan dilindungi. Spesies endemik bersama dengan tumbuhan lain ikut menjadi penyusun vegetasi dalam ekosistem tertentu. Dalam penelitian ini yang dimaksud vegetasi adalah masyarakat tumbuhan di suatu kawasan yang tumbuh dan berinteraksi dengan lingkungannya dan mempunyai karakteristik yang berbeda-beda sesuai dengan lingkungan tempat tumbuhnya. Peran vegetasi sangat penting dalam menjaga kestabilan ekosistem di Pulau Panjang. Vegetasi merupakan habitat dan tempat beraktifitas burung serta berfungsi sebagai sumber makanan, tempat bertengger, tempat bersarang dan berkembang biak. Satwa liar yang banyak dijumpai di Pulau Panjang adalah dari kelompok burung. Burung di Pulau Panjang merupakan satwa yang dilindungi undang-undang dan tertuang dalam SK Bupati Jepara No. 246 Tahun 2010 tentang penetapan jenis/spesies burung yang dilindungi di Pulau Panjang. Berdasarkan latar belakang diatas maka tujuan 
penelitian ini adalah untuk mendeskripsikan jenis-jenis tumbuhan yang terdapat di Pulau Panjang, Jepara.

\section{METODE PENELITIAN}

Penelitian ini merupakan penelitian deskriptif (Hamdi, 2014). Metode yang digunakan adalah metode observasi yaitu mengumpulkan gambaran umum karakteristik sampel di seluruh areal penelitian (Hamdi, 2014). Kawasan yang dijadikan tempat penelitian merupakan kawasan pesisir Pulau Panjang, Desa Ujungbatu, Kecamata Jepara, Kabupaten Jepara dengan luas 7 hektare. Penelitian ini dilaksanakan pada tanggal 27 Juli 2019. Teknik analisis data yang digunakan dalam penelitian ini adalah deskripsi keanekaragaman hayati hutan pantai. Data tumbuhan pantai yang ditemukan dianalisis secara deskriptif dengan membuat deskripsi dan klasifikasi spesimen yang ada.

\section{DATA DAN PEMBAHASAN}

Hasil identifikasi tanaman terrestrial yang menempati ekositem hutan pantai Pulau panjang, ditemukan 15 species utama, sebagai berikut:

\section{Kenanga}

$\begin{array}{ll}\text { Kingdom } & \text { : Plantae } \\ \text { Divisi } & \text { : Magnoliophyta } \\ \text { Kelas } & \text { : Magnoliopsida } \\ \text { Ordo } & \text { : Magnoliales } \\ \text { Famili } & : \text { Annonaceae } \\ \text { Genus } & \text { : Phaenthus } \\ \text { Spesies } & : \text { Phaenthus } s p .\end{array}$

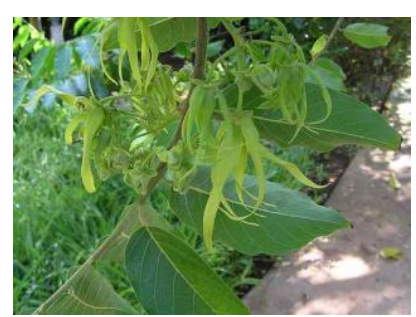

Gambar 1. Bunga kenanga 
Kenanga masuk ke dalam golongan pohon. Berdasarkan hasil pengamatan didapatkan ciri-ciri antara lain: pohonnya dapat mencapai $30 \mathrm{~m}$. batang lurus, kayu keras, kulit batangnya berwarna abu-abu keputihan. Daunnya berbentuk lonjong, halus dan berkilau. Bunga majemuk tandan terjurai berwarna hijau, tetapi bila sudah tua berubah menjadi kuning dan baunya sangat harum. Buah berbentuk bulat telur terbalik berwarna hijau ketika masih muda, dan menjadi kehitaman setelah tua. Panjang buahnya $1 \mathrm{~cm}$, dan berdaging tebal (Syamsul dan Napitupulu, 2015). Kenanga bukanlah tanaman endemik di Pulau Panjang, kenanga banyak ditemui di sekitar Syeikh Abu Bakar Pulau Panjang. Diperkirakan tanaman ini dibawa oleh para peziarah yang datang.

2. Kelapa

$\begin{array}{ll}\text { Kingdom } & \text { : Plantae } \\ \text { Divisi } & \text { : Magnoliophyta } \\ \text { Kelas } & \text { : Liliopsida } \\ \text { Ordo } & \text { : Arecales } \\ \text { Famili } & : \text { Arecaceae } \\ \text { Genus } & : \text { Cocos L. } \\ \text { Spesies } & : \text { Cocos sp. } \\ & \end{array}$

Gambar 2. Pohon kelapa

Kelapa masuk ke dalam golongan pohon. Berdasarkan hasil pengamatan didapatkan ciri-ciri antara lain: Sistem perakarannya serabut, batangnya tumbuh lurus ke atas dan tidak bercabang, tinggi batang dapat mencapai $30 \mathrm{~m}$, dengan garis tengah batang antara 20-30 cm. Daun kelapa bersirip genap dan bertulang sejajar. Daun memiliki pelepah daun, di mana terdapat anak-anak daun pada sisi kanankirinya. Bunga kelapa merupakan bunga berkarang (Warisno, 2003). Tanaman 
kelapa ini banyak ditemui di daerah pesisir pantai. Kelapa pada awalnya berasal dari kepulauan pasifik yang kemudian bijinya tersebar melalui arus laut ke berbagai daerah bumi. Pohon kelapa sangat cocok tumbuh di pulau panjang karena tanahnya berpasir, kelembapan tinggi, curah hujan tinggi, serta peraiaran yang asin.

3. Pepaya

$\begin{array}{ll}\text { Kingdom } & \text { : Plantae } \\ \text { Divisi } & \text { : Magnoliophyta } \\ \text { Kelas } & \text { : Magnoliopsida } \\ \text { Oro } & \text { : Brassicales } \\ \text { Famili } & \text { : Caricaceae } \\ \text { Genus } & \text { : Carica L. } \\ \text { Spesies } & \text { : Carica papaya L. }\end{array}$

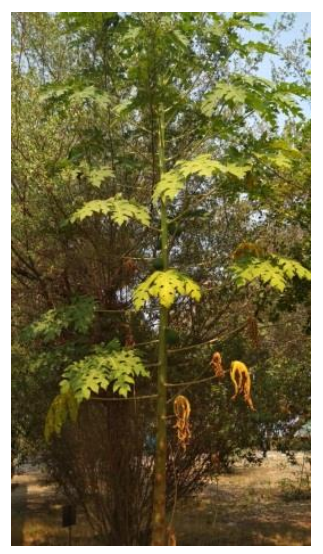

Gambar 3. Pohon pepaya

Pepaya masuk ke dalam golongan pohon. Berdasarkan hasil pengamatan didapatkan ciri-ciri antara lain: papaya memiliki sistem perakaran tunggang dan akar bercabang. Batang berbentuk bulat lurus, berbuku-buku, berongga di bagian tengahnya, dan tidak berkayu. Daun papaya bertulang menjalar, dengan warna hijau tua pada bagian atasnya dan tua muda di bagian bawahnya. Pepaya memiliki tiga jenis bunga yaitu bunga jantan, bunga betina, dan bunga sempurna (banci) (Suprapti, 2005). Tanaman pepaya bisa tumbuh di pulau panjang diperkirakan penyebarannya disebabkan oleh bijinya dibawa oleh burung pemakan biji.

4. Ketapang

Kingdom : Plantae

Divisi : Magnoliophyta 


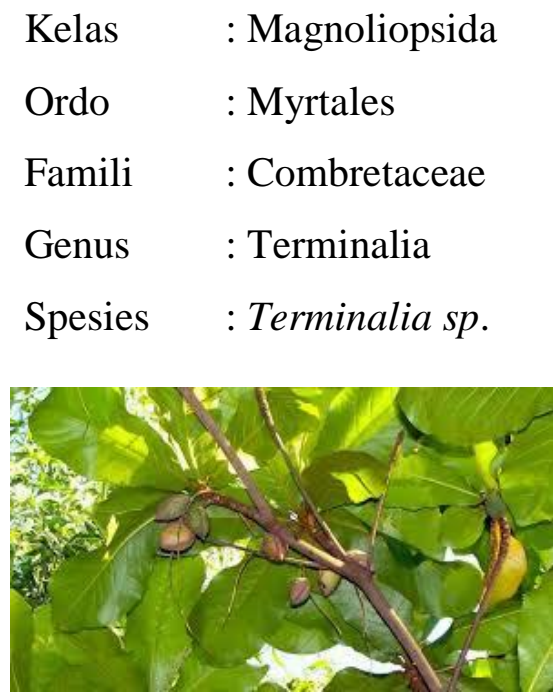

Gambar 4. Buah ketapang

Ketapang masuk ke dalam golongan pohon. Berdasarkan hasil pengamatan didapatkan ciri-ciri antara lain: ketapang dapat tumbuh hingga mencapai $40 \mathrm{~m}$ dan diameter mencapai $2 \mathrm{~m}$. dapat hidup di ketinggian 800 dpl. Kulit sepat dan banyak memar. Daun berbentuk bulat telur. Bunga tidak berwarna, tetapi memiliki bau harum (Readaksi AgroMedia, 2008). Sebagian tanaman ketapang tumbuh di pulai ini dengan sendirinya dengan penyebaran biji melalui arus laut, namun sebagian lagi ditanam oleh Pemerintah Daerah Kabupaten Jepara sebagai upaya perlindungan vegetasi kawasan ini.

5. Kayu Besi

Kingdom : Plantae

Divisi : Magnoliophyta

Kelas : Magnoliopsida

Ordo : Fabales

Famili : Fabaceae

Genus : Intsia

Spesies : Intsia sp. 


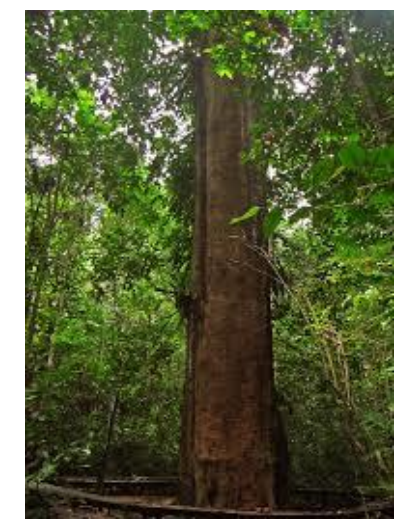

Gambar 5. Pohon kayu besi

Kayu besi masuk ke dalam golongan pohon. Berdasarkan hasil pengamatan didapatkan ciri-ciri antara lain: Tinggi pohon dapat mencapai $35 \mathrm{~m}$ dengan panjang batang bebas cabang 5-20 m, diameter sampai 100-150 cm. kayu besi umumnya tumbuh pada 5-400 $\mathrm{m}$ di atas permukaan laut dengan medan datar sampai miring, tumbuh terpencar, atau mengelompok dalam hutan campuran (Ningsih, 2015). Pada tahun 2016, mahasiswa dari UNISNU melakukan penanaman pohon besi ini untuk menciptakan suasana sejuk dan teduh di Pulau Panjang, sehingga pohon ini banyak ditemui di lokasi.

6. Asam

Kingdom : Plantae

Divisi : Magnoliophyta

Kelas : Magnoliopsida

Ordo : Fabales

Famili : Fabaceae

Genus : Tamarindus L.

Spesies : Tamarindus indica L.

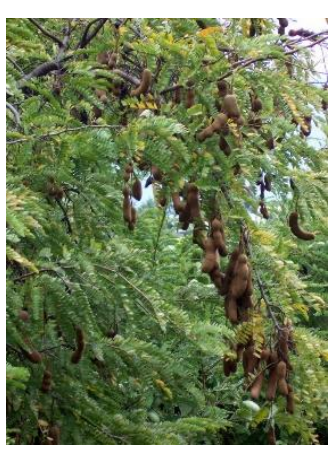

Gambar 6. Pohon asam 
Asam masuk ke dalam golongan pohon. Berdasarkan hasil pengamatan didapatkan ciri-ciri antara lain: tinggi pohon antara 20-30 m, dan lingkar batang lebih dari $7 \mathrm{~m}$. kulit batang berwarna coklat keabu-abuan dan tidak rata permukaannya. Bentuk daun bylat memanjang, kecil, dan tipis. Warna daun hijau muda sampai hijau tua, helaian daun tersusun dalam tangkai daun, dudk daun berhadap-hadapan. Bunga tanaman asam termasuk bunga majemuk, berwarna kuning kemerah-merahan. Buah asam berbentuk polng tipis, kulit polong berwarna seperti karat besi. Daging buah berwarna coklat sampai coklat tua atau merah (Rukmana, 2005). Tanaman ini baik untuk pencegah terjadinya abrasi di Pulau Panjang. Selain itu juga agar kawasan pulau nampak teduh.

7. Lamtoro

$\begin{array}{ll}\text { Kingdom } & \text { : Plantae } \\ \text { Divisi } & \text { : Magnoliophyta } \\ \text { Kelas } & \text { : Magnoliopsida } \\ \text { Ordo } & \text { : Fabales } \\ \text { Famili } & \text { : Fabaceae } \\ \text { Genus } & \text { : Leucaena } \\ \text { Spesies } & \text { : Leucaena sp. }\end{array}$

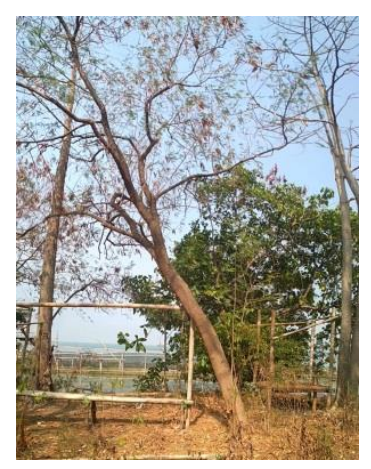

Gambar 7. Pohon lamtoro

Lamtoro masuk ke dalam golongan perdu pohon. Berdasarkan hasil pengamatan didapatkan ciri-ciri antara lain: tinggi pohon mampu mencapai 5-15 m. Tanaman tumbuh tegak, daunnya kecil, tulang daun menyirip ganda dua dengan jumlah pasangan 4-8 pasang, tiap sirip tangkai daun mempunyai 11-22 helai daun. Bunganya merupakan bunga bangkol, bunga majemuk menyerupai cawan tepi tanpa daun pembalut, berbentuk bola dan berwarna putih, batangnya berwarna putih 
kecoklatan atau coklat kemerah-merahan (Puwanto, 2007). Tanaman ini diperkirakan penyebarannya dibantu oleh burung yang tinggal di pulau ini.

8. Kapuk Randu

$\begin{array}{ll}\text { Kingdom } & \text { : Plantae } \\ \text { Divisi } & \text { : Magnoliophyta } \\ \text { Kelas } & \text { : Magnoliopsida } \\ \text { Ordo } & : \text { Malvales } \\ \text { Famili } & \text { : Malvaceae } \\ \text { Genus } & \text { : Ceiba Mill } \\ \text { Spesies } & \text { : Ceiba } s p .\end{array}$

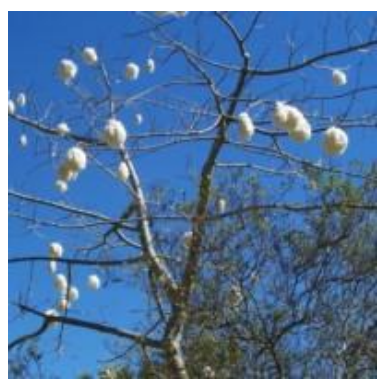

Gambar 8. Pohon kapuk randu

Kapuk randu merupakan tumbuhan yang masuk ke dalam jenis pohon. Berdasarkan hasil pengamatan didapatkan ciri-ciri antara lain: tinggi pohon kapuk mencapai 8-30 m. dan memiliki diameter batang hingga $3 \mathrm{~m}$. Daunnya bertangkai panjang dan berbilang 5-9. Bunga terkumpul di ketiak daun yang sudah rontok. Pohon kapuk memiliki buah yang bentuknya memanjang, menggantung, berkulit keras, dan berwarna hijau jika masih muda dan berwarna coklat jika telah tua. Dalam buahnya terdapat biji yang dikelilingi bulu-bulu halus, serta kekuning-kuningan yang merupakan campuran dari lignin dal selulosa. Bentuk bijinya bulat, kecil-kecil, dan berwarna hitam. Tanaman ini diperkirakan penyebarannya dibantu oleh burung yang tinggal di pulau ini.

9. Waru

$\begin{array}{ll}\text { Kingdom } & \text { : Plantae } \\ \text { Divisi } & \text { : Magnoliophyta } \\ \text { Kelas } & \text { : Magnoliopsida } \\ \text { Ordo } & \text { : Malvales } \\ \text { Famili } & \text { : Malvaceae }\end{array}$


Genus : Hibiscus

Spesies : Hibiscus sp.

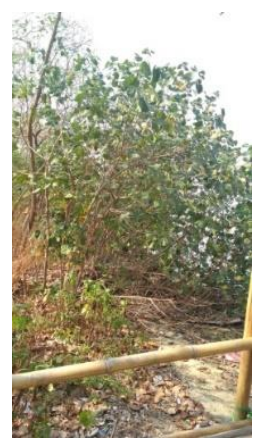

Gambar 9. Pohon waru

Waru merupakan tumbuhan yang masuk ke dalam jenis pohon. Berdasarkan hasil pengamatan didapatkan ciri-ciri antara lain: memiliki tinggi 5-15 m garis tengah batang 40-50 cm bercabang dan berwarna coklat. Daun tunggal, berangkai berbentuk jantung, lingkaran lebar, dan tidak berlekuk. Daun menjari sebagian dari tulang daun utaman dengan kelenjar berbentuk celah pada sisi bawah dan sisi pangkal, sisi bawah daun berambut dan berwarna hijau keabu-abuan. Bunga waru merupakan bunga tunggal bertaju 8-11. Buah berbentuk telur berparuh pendek, panjang $3 \mathrm{~cm}$. Sebagian tanaman waru disini ditanam oleh Pemerintah Daerah Kabupaten Jepara sebagai upaya perlindungan vegetasi kawasan ini.

10. Kelor

$\begin{array}{ll}\text { Kingdom } & \text { : Plantae } \\ \text { Divisi } & \text { : Magnoliophyta } \\ \text { Kelas } & \text { : Magnoliopsida } \\ \text { Ordo } & \text { : Brassicales } \\ \text { Famili } & \text { : Moringaceae } \\ \text { Genus } & \text { : Moringa } \\ \text { Spesies } & : \text { Moringa } s p .\end{array}$

Kelor masuk ke dalam golongan perdu. Berdasarkan hasil pengamatan didapatkan ciri-ciri antara lain: tinggi batang 7-11 m. Batang berkayu getas, cabang jarang, tapi mempunyai akar kayu yang kuat. Daun berbentuk bulat telur, ukuran kecil dan tersusun majemuk di dalam satu tangkai. Bunga berbau semerbak, berwarna putih kekuningan, dan tulang pelepah bunganya berwarna hijau. Buah berbentuk segitiga memanjang (Redaksi AgroMedia, 2008). 


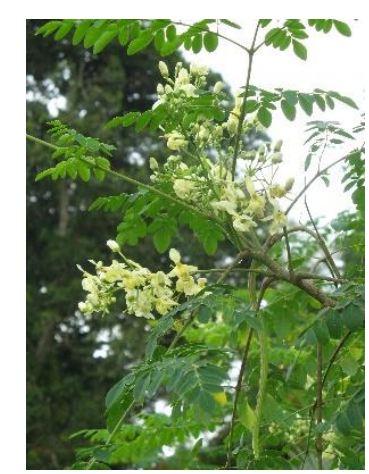

Gambar 10. Pohon kelor

11. Mengkudu
Kingdom : Plantae
Divisi : Magnoliophyta
Kelas : Magnoliopsida
Ordo : Gentianales
Famili : Rubiaceae
Genus : Morinda
Spesies : : Morinda $s p$

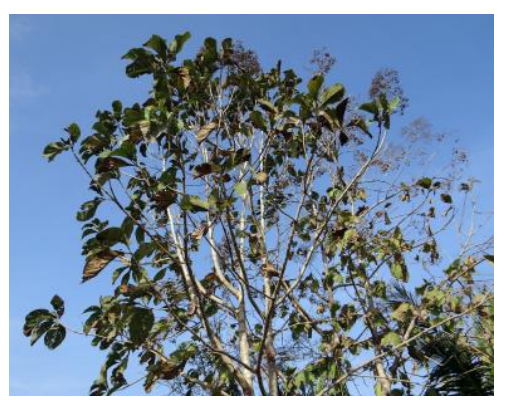

Gambar 11. Pohon mengkudu

Mengkudu masuk ke dalam golongan semak. Berdasarkan hasil pengamatan didapatkan ciri-ciri antara lain: kulit batang keabu-abuan atau coklat kekuningan. Daun tunggal, berbentuk jorong melanset dengan panjang 10-40 cm, mengilap. Perbungaan bongkol gundul. Bunga harum dan berwarna putih. Buah lonjong, panjangnya sampai $15 \mathrm{~cm}$, berwarna hijau keputihan dengan bau yang kurang sedap ketika masak, berbiji banyak berwarna hitam kecoklatan (Syamsul dan Napitupulu, 2015). 


\section{Jati Pasir}

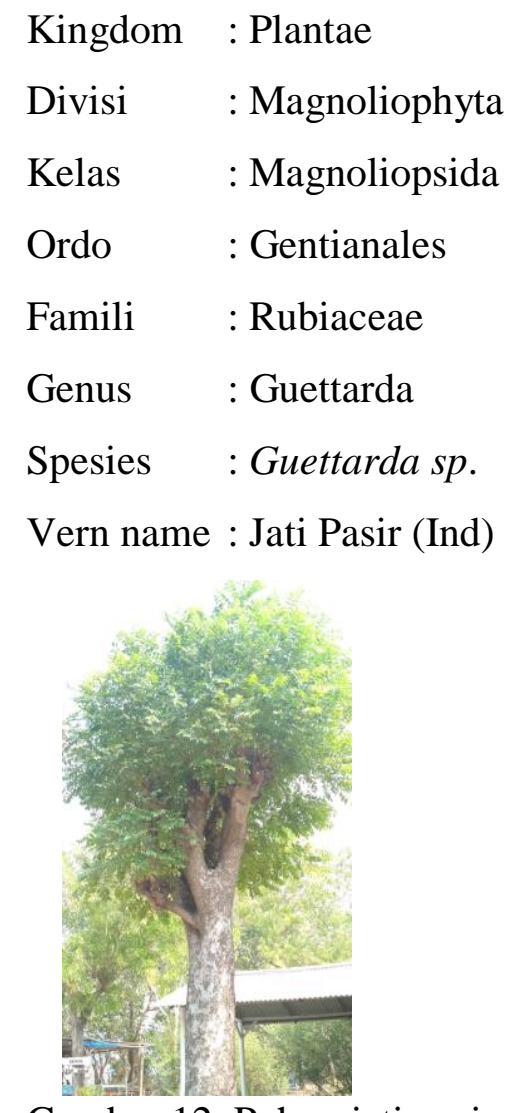

Gambar 12. Pohon jati pasir

Jati pasir merupakan tumbuhan yang masuk ke dalam jenis pohon. Berdasarkan hasil pengamatan didapatkan ciri-ciri antara lain: tingginya bisa mencapai $22 \mathrm{~m}$. daunnya bertangkai dan memiliki bilah dengan ujung kecil, berwarna hijau kekuning-kuningan. Bunganya berwarna putih dengan tabung kekuning-kuningan. Bunganya terbuka sekitar satu jam setelah matahari terbenam, dan lingkaran bunga jatuh keesokan paginya. Buahnya samar, dan berusuk rapat, berwarna hijau keputihan, atau merah muda.

13. Sawo
Kingdom : Plantae
Divisi : Magnoliophyta
Kelas : Magnoliopsida
Ordo : Ericales
Famili : Sapotaceae
Genus : Manilkara
Spesies : : Manilkara sp. 


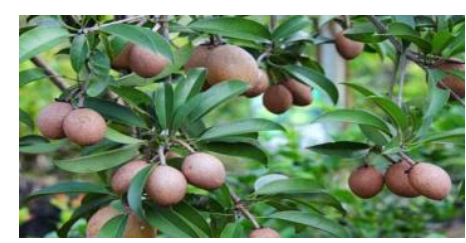

Gambar 13. Buah sawo

Sawo masuk ke dalam jenis pohon. Berdasarkan hasil pengamatan didapatkan ciri-ciri antara lain: batangnya berkulit kasar abu-abu kehitaman sampai coklat tua. Daun tunggal terletak berseling, pangkal dan ujungnya berbentuk baji. Bunga tunggal terletak di ketiak daun dekat ujung ranting. Buah buni bertangkai pendek, bulat, bulat teur, atau jorong, berwarna coklat kemerahan, berkulit tipis, daging buah lembut dan manis. Berbiji lonjong pipih dengan warna coklat kehitaman (Syamsul dan Napitupulu, 2015).

14. Stigi
Kingdom : Plantae
Divisi : Magnoliophyta
Kelas : Magnoliopsida
Ordo : Myrtales
Famili : Lythraceae
Genus : Pemphis
Spesies : Phempis acidula

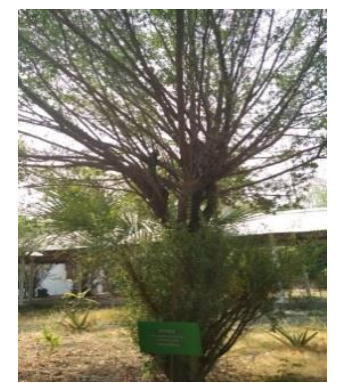

Gambar 14. Pohon stigi

Stigi masuk ke dalam jenis pohon. Berdasarkan hasil pengamatan pohon khas pesisir ini memiliki tinggi 4-10 m. Batang berkelok dengan percabangan yang tidak teratur. Kulit batang berwarna abu-abu hingga coklat tua dan bersisik. Daun tunggal dan tumbuh bersilangan. Berwarna hijau pucat, berdaging tebal, berbentuk elips. Bunga stigi berwarna putih atu merah muda keputihan dengan tumbuh di ketiak daun. Buah stigi berwarna hijau dengan permukaan buah berambut mengandung banyak biji yang sangat kecil. 
15. Cemara Laut

$\begin{array}{ll}\text { Kingdom } & \text { : Plantae } \\ \text { Divisi } & \text { : Magnoliophyta } \\ \text { Kelas } & \text { : Magnoliopsida } \\ \text { Ordo } & : \text { Fagales } \\ \text { Famili } & : \text { Casuarinaceae } \\ \text { Genus } & : \text { Casuarina L. } \\ \text { Spesies } & : \text { Casuarina equisetifolia } \text { L. }\end{array}$

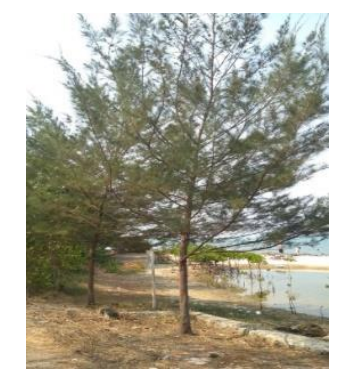

Gambar 15. Cemara laut

Cemara laut merupakan tanaman yang masuk ke dalam jenis pohon. Berdasarkan hasil pengamatan didapatkan ciri-ciri antara lain: tinggi pohon sekitar 6$35 \mathrm{~m}$ dengan diameter $50 \mathrm{~cm}$. Batang kasar, tebal, dan berjalur, lapisan dalam kulit berwarna merah, ranting halus berbentuk jarum, terdapat ruas-ruas, memiliki ranting kecil berwarna hijau. Daun berbetuk gerigi pada buku ranting yang kecil. Memiliki bunga jantan yang bentuknya ringkas memanjang, dan bunga betina mirip seperti bulat berbola atau nanas yang kecil (Chooi, 2004).

Hasil penelitian menemukan 15 spesies yang terdiri atas 10 ordo dan 11 famili, terbagi atas 13 spesies pohon, 1 spesies semak, dan 1 spesies perdu. Adapun beberapa famili yang banyak dijumpai yaitu Fabaceae, Malvaceae, Meliaceae, serta Rubiaceae. Berdasarkan hasil yang diperoleh dari penelitian ini menunjukkan adanya dominasi dari beberapa spesies diantaranya sebagai berikut.

1. Casuarina equisetifolia L. (Cemara Laut). Tumbuhan ini tumbuh pada substrat berpasir di area pesisir tepi pantai Pulau Panjang. Tumbuhan ini paling banyak ditemukan di area bibir pantai dikarenakan pihak Pulau Panjang dan masyarakat sekitar mengadakan konservasi atau pelestarian pohon cemara laut dikarenakan alasannya yang sangat bermanfaat bagi lingkungan dan masyarakat, selain menjadi 
pohon peneduh, cemara laut juga dapat membantu memperbaiki iklim Pulau Panjang.

2. Pemphis acidula (Stigi). Tumbuhan endemik Pulau panjang ini tumbuh pada substrat tanah berpasir, banyak ditemukan di area pemakaman Syekh Abu Bakar, sering juga disebut dengan Taman Stigi. Ditemukannya banyak pohon stigi di area pemakaman disebabkan pohon stigi diyakini oleh masyarakat sekitar sebagai pohon bertuah yang memiliki kekuatan supranatural. Selain itu pohon stigi juga memiliki manfaat untuk kesehatan yaitu sebagai antibisa.

3. Leucaena sp. (Lamtoro), Ceiba sp. (Kapuk Randu), Tamarindus sp. (Asam), dan Terminalia sp. (Ketapang). Kesemua tumbuhan tersebut tumbuh pada substrat tanah berpasir di area dalam Pulau Panjang. Tumbuhan-tumbuhan tersebut banyak ditemukan sebab memberikan banyak manfaat bagi lingkungan dan masyarakat sekitar, misalnya Leucena sp (Lamtoro) memiliki manfaat yaitu sebagai pohon peneduh, pencegah erosi, sumber kayu bakar, dan pakan ternak, selain itu biji lamtoro dapat dimanfaatkan sebagai bahan makanan. Ceiba sp (Kapuk Randu) memiliki manfaat yaitu kayumya digunakan untuk industry mebel, serat kapuk digunakan untuk pengisian bantal, dan kasur, kulit batang randu dapat digunakan sebagai bahan pembuatan tali, daun randu digunakan sebagai obat tradisional. Tamarindus sp (Asam) memiliki manfaat yaitu kayunya dapat digunakan untuk industry mebel, dan buahnya dimanfaatkan sebagai bahan makanan, bumbu, dan penambah rasa asam. Terminalia sp (Ketapang) memiliki manfaat sebagai pohon peneduh, selain itu daun dan kulit batangnya dapat dimanfaatkan sebagai tinta, biji buah ketapang dapat dimanfaatkan sebagai bahan makanan.

\section{SIMPULAN}

Berdasarkan hasil penelitian hutan Pantai di Pulau Panjang Kabupaten Jepara menemukan 15 spesies yang terdiri atas 10 ordo dan 11 famili, terbagi atas 13 spesies pohon, 1 spesies semak, dan 1 spesies perdu. Adapun tanaman yang mendominasi di Pulau Panjang adalah Casuarina equisetifolia L. (Cemara Laut), Pemphis acidula (Stigi), Leucaena sp. (Lamtoro), Ceiba sp. (Kapuk Randu), Tamarindus sp. (Asam), dan Terminalia sp. (Ketapang). 


\section{DAFTAR PUSTAKA}

Bengen, D.G. (2000). Ekosistem dan Sumber Daya Alam Pesisir. Pusat Sumber Daya Pesisir dan Lautan. Bogor: Institut Pertanian Bogor

Chooi, Ong Hean. (2004). Tumbuhan Liar: Khasiat Ubatan dan Kegunaan Lain. Malaysia: Sdn Bhd

Disparbud Jepara. (2020). Statistik Kunjungan Wisatawan Jepara. Tersedia online http://disparbud.jepara.go.id/2020/01/statistik-kunjungan-wisatawan-2019/

Hamdi, Asep Saepul. (2014). Metode Penelitian Kuantitatif Aplikasi Dalam Pendidikan. Yogyakarta: Deepublish.

Mirmanto, E. (2010). Komposisi Flora dan Struktur Hutan Alami di Pulau Ternate, Maluku Utara. Jurnal Biologi Indonesia Vol. 6 No. 3.

Muanmar., Suleman, S.M., Nurdin, M. (2017). Jenis-jenis Tumbuhan di Pesisir Pantai Desa Tibo dan Pemanfaatannya sebagai media pembelajaran. e-JIP BIOL Vol. 5 No. 1.

Ningsih, Sekar. (2015). Buku Pintar Pembibitan Pohon Ulin: Membahas Tentang Pohon Ulin, Jakarta: Lembar Langit Indonesia.

Onrizal., dan Kusmana, C. (2004). Kajian Ekologi Hutan Pantai di Suaka Margasatwa Pulau Rambut, Teluk Jakarta. Jurnal Komunikasi Penelitian, Vol. 16 No. 6.

Pugesehan, D. J. (2011). Analisis Kondisi Hutan di Kawasan Pantai Natsepa Kabupateen Maluku Tengah. Jurnal Agroforestri, Vol. 6 No. 1.

Purwanto. (2007). Mengenal Lebih Dekat Leguminoseae. Jakarta: Kanisius.

Redaksi AgroMedia. (2008). Buku Pintar Tanaman Obat: 431 Jenis Tanaman Penggempur Aneka Penyakit. Jakarta: PT Agromedia Pustaka.

Rukmana, Rahmat. (2005). Asam Budidaya dan Pascapanen. Jakarta: Kanisius.

Suprapti, M. Lies. (2005). Aneka Olahan Pepaya Mentah dan Mengkal. Yogyakarta: Kanisius.

Syamsul, R Hidayat dan Napitupulu, Rodame M. (2015). Kitab Tumbuhan Obat. Jakarta: AgriFlo.

Tuheteru, FD dan Mahfudz. (2012). Ekologi, Manfaat \& Rehabilitasi, Hutan Pantai Indonesia. Manado: Balai Penelitian Kehutanan Manado.

Warisno. (2003). Budi Daya Kelapa Genjah. Yogyakarta: Kanisius. 